\title{
Health during the Cardenismo (1934-1940)
}

\author{
Martha Eugenia Rodríguez \\ Department of History and Philosophy of Medicine, Faculty of Medicine, Universidad Nacional Autónoma de México, Mexico City, Mexico
}

\begin{abstract}
The present symposium, Health during the Cardenismo (1934-1940), consist of four studies: Medical sanitary aspects in Mexico by Martha Eugenia Rodríguez; Campaigns against diseases by Carlos Viesca Treviño; Hospitals during Cardenism by Guillermo Fajardo Ortiz; and Military medicine in Mexico by Antonio Moreno Guzmán. Through them is given an integral vision of the state of health and illness during the administration of General Lázaro Cárdenas del Río, the first sexennial presidential government of the twentieth century. Several aspects are discussed, among them, the President's nationalist policy which led to an important distribution of land to the peasants. His education policy originated, among other things, the creation of the National Polytechnic Institute that framed two medical schools, the National Homeopathic Medicine and the Superior of Rural Medicine. The social service for medical interns of the UNAM was created. On the other hand, General Cárdenas placed special emphasis on preventive and care medicine. In addition to organizing campaigns against multiple diseases, including pox, typhus, tuberculosis, malaria, and sexually transmitted diseases, special attention was given to maternal and child care. An urgent problem was that of malnutrition, so special care was taken in the child and peasant population. Likewise, in order to attend to morbidity, in the period 1934-1940, general and specialty hospitals were set up under government, private, military, and private charitable institutions. The last study that is presented refers to the military health modernization initiatives initiated by General Cárdenas, that had repercussions on the health of the military and its successors.
\end{abstract}

KEY WORDS: Period 1934-1940. Epidemics. Hospitals. Military medical history. Prevention. Medical assistance. Diseases. Campaigns. Military medicine.

\section{Medical-sanitary aspects in Mexico (1934-1940)}

\author{
Martha Eugenia Rodríguez \\ Department of History and Philosophy of Medicine, Faculty of Medicine, Universidad Nacional Autónoma de México, Mexico City, Mexico
}

\section{Introduction}

General Lázaro Cárdenas del Río acted as president of Mexico from December 1, 1934 to November 30,1940 , in the first six-year term government of the $20^{\text {th }}$ century. Cárdenas was the last president that arrived to power under the guardianship of Plutarco
Elías Calles, but he managed to become independent from him, putting an end to the Maximato; i.e., the period encompassed between 1928 and 1934, when Mexico was governed by Emilio Portes Gil, Pascual Ortiz Rubio and Abelardo L. Rodríguez, who were dominated by Elías Calles, president of the country from 1924 to 1928 and known as the "maximum chief of the revolution" (hence the term Maximato).

\section{Correspondence:}

Gac Med Mex. 2017;153:553-569

Contents available at PubMed www.gacetamedicademexico.com 
Table 1. INEGI

\begin{tabular}{|c|c|c|c|c|}
\hline Year & Country & Inhabitants & Capital city & Inhabitants \\
\hline 1921 & Estados Unidos Mexicanos & 14334780 & Distrito Federal & 906063 \\
\hline 1930 & Estados Unidos Mexicanos & 16552722 & Distrito Federal & 1229576 \\
\hline 1940 & Estados Unidos Mexicanos & 19653552 & Distrito Federal & 1757530 \\
\hline
\end{tabular}

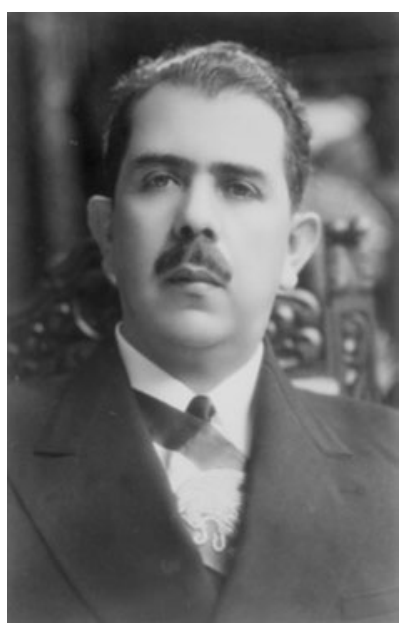

Figure 1. General Lázaro Cárdenas del Río, officeholder of the first six-year term government of Mexico in the $20^{\text {th }}$ century.

In the international scenario, the rise of fascism and Nazism was taking place in Europe, as well as the good neighbor policy established by the president of the USA, Franklin D. Roosevelt, towards Latin American countries ${ }^{1}$.

The type of politics that was to be undertaken by Cardenas government was characterized by its nationalism, by trying to reach socioeconomic balance, by intensifying land distribution and by the need to unify and organize workers, so he expropriated latifundia of the revolutionary times from Mexicans and foreigners in order to distribute them in the form of common lands among peasants, as it was the case of the Lagunera Region in Durango and Coahuila on one hand, and the henequen zone in Yucatán, just to mention some examples. This way, Cárdenas made the greatest land distribution ever, creating more than 11,000 shared lands, which accounted for $10 \%$ of the national territory ${ }^{2}$ (Fig. 1).

In 1930, Mexico had 16.5 million inhabitants, out of which 11 million resided in rural and 5.5 in urban settlements ${ }^{3}$. It should be mentioned that the Cardenismo public health politics focused on population growth, in order for natural resources of the country to be better exploited and definitive progress to be achieved (Table 1).

On the other hand, the Confederation of Workers of Mexico, created in 1936 under the direction of Vicente
Lombardo Toledano, a convinced militant of the construction of a socialist society, cemented the labor movement that sympathized with the government. Cárdenas tolerated workers and peasants movements, the creation of unions and strikes in transportation, mining and oil companies ${ }^{4}$.

The Cardenista ideological mainstay was the defense of national sovereignty against external threat, and a proof of this policy was the nationalization of the railway system in 1937 and the expropriation of the oil industry on March 18 of the following year, given that $100 \%$ of the industry was in foreign hands.

\section{Education and culture}

For his cultural politics, Cárdenas implanted three guiding ideas: Indigenism, nationalism and social justice. So we see, for example, how art became politicized, as confirmed by the Mexican muralist movement led by José Clemente Orozco, Diego Rivera and David Alfaro Siqueiros ${ }^{5}$. All three belonged to the painters and sculptors union, trying to recover the art of mural painting under government sponsorship.

In a separate issue, at his address to the Congress on September 1, 1935, General Cárdenas announced the creation of the National Polytechnic Institute in order for "the masses, particularly the proletarian ones, to receive technical training, so that each individual in the Mexican Republic can be a more competent social unit for the collective exercise..."' ${ }^{\prime \prime}$ The Polytechnic had several schools, including the National School of Homeopathic Medicine, which was founded in 1889, but was integrated to the Polytechnic by means of a decree. Similarly, said institute harbored the National School of Biological Sciences, which in 1938 fostered the creation of the Rural Medicine Higher Education School, which was known by this name until $1965^{7}$. Within that context, president Cárdenas devoted his efforts to extend health services to the vulnerable population, particularly to peasants. With the social orientation that characterized the latter School, which offered technical training on public health general aspects, the Mexican government expected to solve day-to-day medical problems. 


\section{Social Service}

In agreement with Cárdenas government national politics, the Social Service for National University medical intern students was created in 1936. Its establishment represented a way to solve a series of social problems, especially in rural areas; to repay to society and to benefit the most needed population, and an agreement was therefore established with the Department of Public Health, which was the medical regulatory institution, and the National Autonomous University of Mexico (UNAM), then directed by Dr. José Siurob Ramírez and the lawyer Luis Chico Goerne, respectively. For that purpose, Dr. Gustavo Baz Prada, director of the National School of Medicine, considered the intern as a promoter to work at rural communities of the country, pointing out in the speech he addressed to the first generation that was to "practice their profession among primitive and very rude people, uneducated children of the mountains, the woods and the wasteland, who haven't the faintest notice of what the modern art of healing is". This way, Dr. Baz indicated that social service would be a requirement to obtain the physician degree and that it would consist of 5 months of practice in rural zones ${ }^{9}$. However, administrative procedures and transportation issues reduced effective work to 3.5 months, and for this reason, social service was subsequently extended to one year. Mr. Roberto García Formentí was the first head of the physician distribution office.

\section{Spanish exiles}

With the Spanish Civil War and the Republican defeat in 1939, when Francisco Franco dictatorship was established, there was an estimate of more than 6000 Spanish refugees registered in Mexico ${ }^{10}$. In that context, a considerable group of intellectuals had a place in our leading academic institution. Eminent intellectual figures arrived and contributed to the development of Mexican law, philosophy, biology, chemistry and medicine, including Isaac Costero Tudanca (19031979), who was member of the Spanish Histology School, directed by Santiago Ramón y Cajal. Doctors Tomás G. Perrín and Ignacio Chávez encouraged Costero Tudanca to continue his teaching and anatomopathological research works at the General Hospital, the UNAM and the National Institute of Cardiology. As a matter of fact, it was Costero who started the second epoch of anatomopathological research in Mexico, since the one started by Rafael Lavista and Manuel Toussaint was interrupted by the 1910 revolutionary movement. During the performance of his activities, the prominent Spanish physician stated that "scientific discovery must be followed by its philosophical interpretation", thus establishing methodological bases for research ${ }^{11}$. One fact to be highlighted, and in recognition of Costero Tudanca's trajectory, is that in 1968 he was elected to chair the National Academy of Medicine of Mexico.

\section{The six-year plan and medicine}

The government plan for the 1934-1940 period pointed at several aspects in favor of preventive medicine and medical assistance, which would be analyzed and addressed by the medical regulatory institution, the Department of Public Health. During the six-year term, the incumbent directors of that institution were Abraham Ayala González (1934-1935), José Siurob Ramírez (1935-1938), Leonides Andrew Almazán (1938-1939) and again Siurob (1939-1940).

Of the federal budget, an amount was reserved for public health, and it was to be gradually increased in order to broaden sanitary services, including running water and sewage systems. With regard to the health budget, in 1935 it was 7.4 million pesos, which accounted for $3.4 \%$ of the gross domestic product (GDP). In 1929, it was 16.5 million pesos; i.e., $5.5 \%$ of the GDP. There was interest to reserve this budgetary increase for workers and peasants health, given that they represented important sources of energy for the country ${ }^{12}$.

President Cardenas was committed to tackle prevailing diseases, particularly typhoid fever, measles, scarlet fever, pertussis, diphtheria, malaria, yellow fever and typhus; to fight epidemics and endemic diseases, including tuberculosis, leprosy, syphilis, malaria, onchocerciasis and smallpox; to train public health technical personnel to cover the entire national geography; to address people's nutrition and to give continuity to decentralized work by means of the Coordination and Cooperation of Federal and Local Sanitary Services of the Republic.

An important point of Cardenas government was childhood protection and the fight against childhood mortality. Dr. José Siurob, head of the Department of Public Health used to say: "Childhood protection is not a sentimental or charity issue, but it is a serious social problem that implies the creation of a healthy and strong population", that would constitute the nation unity. Thus, protection of children started from pre-marriage exams to surveillance of pregnancy and delivery, breastfeeding advocacy and supervision of infants' growth ${ }^{13}$. 


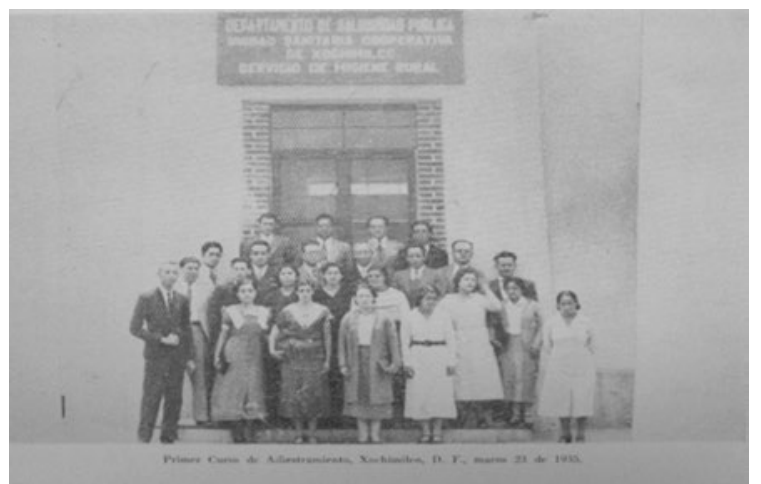

Figure 2. Impartation of the first training course of the Rural Hygiene Service, 1935. (In: J. Álvarez Amézquita, Historia de la Salubridad y de la Asistencia en México, 1960.)

When Cardenas government started, yearly mortality statistics ${ }^{14}$ in 1935 were the following:

- 100,000 of the children's population

- 83,000 digestive system-associated.

- 62,000 respiratory system-associated.

- 25,000 malaria-associated.

- 12,000 tuberculosis-associated.

- 7000-8000 smallpox-associated.

- 6000 dysentery-associated.

Campaigns for the prevention and care of these diseases were intensified, with the visiting nurse acquiring importance, since she was in charge of imparting education on hygiene. After talking to the patients, using plain language, she gave a summarized "scientific explanation" about disease transmission. Sanitary nurses had to have knowledge about diseases of mandatory report, etiology, sources of infection, form of transmission, incubation period, infection period, diagnostic guidelines, preventive measures, immunizations and investigation of carriers. In addition, the nurse could intervene in social aspects, such as nutrition and housing improvement ${ }^{15}$. In brief, the role of the sanitary nurse was highly relevant (Fig. 2).

On the other hand, a set of regulations were issued on August 16, 1935 to fight smallpox, stating the mandatory nature of vaccination. The instruction also contemplated that the bosses of public and private establishments, such as prisons and military and police corporations, had the commitment to vaccinate their members. The Church would only perform confirmations when the child's vaccination record was presented.

In addition, the Department of Public Health promoted social medicine and paid attention to problems that were lived from day to day, such as alcoholism and prostitution. Moreover, it linked poverty with disease, by analyzing the scenario the patient lived in. Therefore, this Department, together with Federal Sanitary Services, developed joint tasks: first, by trying to find out the factors that generated diseases, such as the population costumes, by identifying the type of weather and household they lived in; and in second term, by making inspections of foods and beverages, undertaking sanitary engineering works (such as, for example, latrines), eliminating mosquitoes and calculating statistics in order to know the number of subjects affected by a given disease.

\section{Comments}

The Cardenista directive, which aimed to reach equity among the Mexican population, oriented its health politics towards the prevention of diseases, fundamentally children's diseases and, in second term, it addressed therapeutic care, particularly for workers and peasants. Similarly, it was interested in social campaigns, such as the anti-alcoholism campaign, in order to create awareness in the Mexican population ${ }^{16}$.

Eradication of diseases was public health central subject, which was not only an instrument for optimizing the economy, but also for improvement at the individual level. Therefore, by means of campaigns and mobile sanitary brigades, priority was given to the care of diseases of the digestive and respiratory systems, as well as to the causes that produced them, and the Cardenista government therefore paid attention to different issues, such as food and water poor quality, in addition to undertaking sanitary engineering works.

In Álvarez Amézquita's opinion ${ }^{17}$, at the conclusion of Cárdenas six-year term, there was significant progress regarding healthcare matters. This achievement was due to different organizations' joint work, including the Department of Public Health as the institution that regulated the practice of medicine, the Institute of Hygiene, the School of Public Health, the Institute of Public Health and Tropical Diseases, the Ministry of Public Assistance and the centers of rural hygiene distributed across the entire national territory. Doctors played an important role, but sanitary nurses, social workers, engineers and technicians also did. All of them joined efforts to work for integrated national development.

With regard to politics, although it is true that the socialist tendency was then widely accepted among the population, Cárdenas radicalism fragmented the country. In 1939, the National Action Party (PAN) was created under the direction of the lawyer Manuel Gómez Morín ${ }^{18}$, and not only internal oppositions did multiply, but also those of foreign interests affected by expropriations, and hence, in the following administrations, political life changed its directive. 


\title{
Campaigns against disease during the Cardenismo
}

\author{
Carlos Viesca Treviño \\ Department of History and Philosophy of Medicine, Faculty of Medicine, Universidad Nacional Autónoma de México, Mexico City, Mexico
}

\section{Introduction}

Lázaro Cárdenas presidential term, from 1934 to 1940, marked the beginning of a tendency towards stability in the country and opened the possibility for the development of ideals and ideology of the Mexican Revolution. Two priority aspects of his politics and government were education and health, two areas where actions that established the direction both would take and follow in the next decades were carried out.

\section{4 six-year plan and its conversion into actions}

Prepared between 1933 and 1934, this first six-year plan established a commitment by the head of the executive branch to establish defined political guidelines and to carry out a series of actions conductive to the solution of concrete problems. In the field of health, the need to reestablish hygienic conditions lost during the years of armed conflict was clearly established, along with the recovery of the hospital network by updating and modernizing it, but, especially, the need to carry out an objective study of the problems to be tackled by developing a systematic capture of statistical data and carrying out concerted actions in order to fight transmittable diseases, as well as endemic diseases and epidemics foci. The importance and urgency of promoting health policies that responded to already known and newly detected needs was undeniably recognized ${ }^{19}$.

At his first annual government report on September 1, 1935, Cárdenas reaffirmed there was an open road for a public policy directed "to intensify hygienization and health-related propaganda" both in the cities and rural areas ${ }^{20}$. At 10 months of having taken office, Cárdenas claimed that "important vaccination campaigns" had been carried out in "all sectors of the country", that a Department of Industrial Hygiene had been created in order to "protect field and city workers' health", as well as installation of anti-tuberculosis dispensaries, intensification of the battle against venereal diseases, fight against onchocerciasis, pinta and leprosy. Stress was made on the urgency to provide the population with potable water, given the high incidence of gastrointestinal diseases and associated death ${ }^{21}$.

\section{Some revealing data: statistics reveal changes from 1934 to 1940}

In 1930 , the population of the country was $16,552,782$ inhabitants, and by 1949 , it had increased to $19,650,000$ inhabitants, $1,800,000$ of them in Mexico City. Life expectancy at birth, which was 33 years, increased to 41.5 years; the death rate went from 26.6 to 22.8 per 1000 population, and mortality of children younger than 1 year went from 250 to 24.5 per 1000 live births. The birth rate remained stable at 44.6 per 1000 population 22,23 .

\section{An epidemiological vision in 1934}

In 1934, Miguel Bustamante, who then was sub-director of the brand-new Directorate of Coordinated Services, presented a comprehensive vision of the country's epidemiological conditions. His analysis essentially focused on causes of death, pointing out that, in general terms, most States of the Republic had yearly mortality rates ranging from 31 to 40 per 1000 population, with a general coefficient that never was lower than 26 per 1000. By 1934, pneumonia and acute respiratory diseases were the first cause of death, followed by diarrhea and enteritis, with typhoid and paratyphoid fever at second place, malaria at third, followed by measles and whipping cough and with smallpox at sixth place. Of note, $42.6 \%$ of deaths were due to infectious and parasitic-origin diseases, and this didn't change during the six-year period, although it started to gradually decrease after 1940 . The comparison with figures originating in other countries led to consider ours as deficient with regard to its hygienic conditions and invoked the imperative need to organize health-related services aiming to implement the necessary treatments and prevention measures ${ }^{24}$.

The central doctrine that was invoked to promote changes in public health and medical care policies was that of social medicine, supported by Alfonso Angelini since 1933, which was going to be the Cardenismo health politics main flag ${ }^{25}$. 


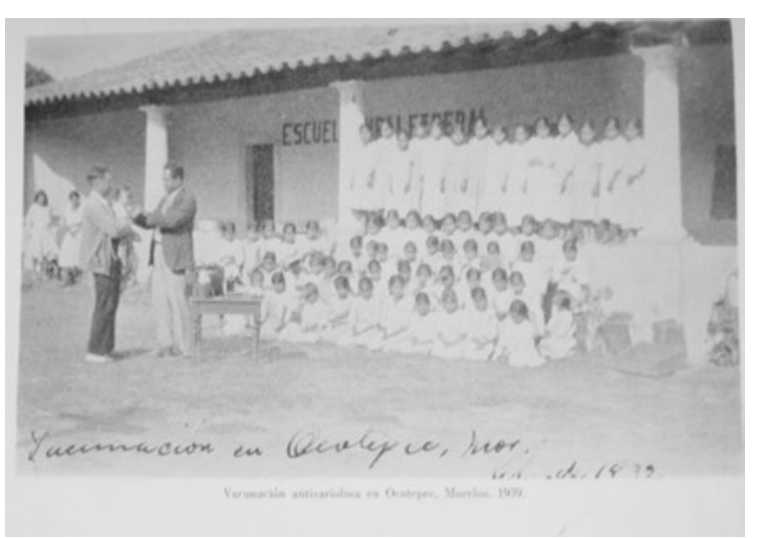

Figure 3. Smallpox vaccination campaign. Department of Public Health, 1934. (In: J. Álvarez Amézquita. Historia de la Salubridad y de la Asistencia en México.1960)

\section{Smallpox}

The Administration that preceded Cárdenas witnessed the efforts of doctors Gastón Melo, Manuel Gea González and Manuel Madrazo to promote smallpox vaccination, and the results didn't take long to be palpable: from 17,405 deaths in 1930 , mortality had declined to 6,094 in 1933, a figure that increased to 9,430 in 1934 , owing to the epidemic outbreak that affected settlements from the mountains of Oaxaca and large part of Chiapas. For the next year, 1935, $6,000,000$ doses were applied and new vaccination and revaccination regulations were concurrently made public. In 1936 there was an outbreak in Tlapacoya, Veracruz, which was controlled in 3 months and followed by intense campaigns in Oaxaca, particularly in Pochutla, Candelaria, Tuxtepec, Putla, Silacayoapan and Ocotlán ${ }^{26}$. The end result was that, during General Cárdenas six-year government period, the smallpox mortality rate went on gradually decreasing from 5205 cases in 1935 to 1341 in 1940, which was markedly favored by the conscientious production of the vaccine by the Institute of Hygiene ${ }^{27}$. There was to be a new outbreak in 1941 that continued until 1943, that is, when Cárdenas term had already concluded, but it should be mentioned that it was vigorously and opportunely fought, and that continuity of actions was achieved beyond government changes, which led to eradication of the disease in $1952^{28}$ (Fig. 3).

\section{Typhus}

Although there were no important typhus epidemic outbreaks during the period here referred, this disease remained a constant concern, particularly owing to important epidemics and multiple outbreaks that occurred during the years of the Revolution and in the many military uprisings of subsequent years. The last outbreak of considerable magnitude took place in the capital city in 1929, and barracks, orphanages, prisons and hospitals endlessly documented cases in spite of delousing measures, which were increasingly constant. After having isolated the rickettsia causative of Mexican typhus in the previous decade, by means of personal works and those made in collaboration with Kans Zinsser and Hermann Mooser, in 1937, Maximiliano Ruiz Castañeda opened the laboratory of studies on typhus at the General Hospital, which would ultimately develop an effective typhoid vaccine that was systematically used in the campaigns implemented for that purpose and that would be presented by the Mexican Government to be used in Poland for the terrible epidemic that ravaged this country as a result of the German invasion ${ }^{29}$.

\section{Tuberculosis}

A few months prior to Cárdenas inauguration as president on February 1934, Manuel Gea González had set the Anti-tuberculosis Campaign in motion, picking up Liceaga's idea about organizing systems for early detection of the disease, immediate treatment implementation and to promote the construction of a hospital specialized in the management of these patients. Soon, the constriction of what was going to be the Huipulco Hospital was initiated, and it was opened on December 31, 1935. It was also in 1935 when the anti-tuberculosis vaccine with the Calmette-Guerin bacillus started being prepared by the Institute of Hygiene and, in 1938, the use of von Pirquet and Mantoux reactions and PPD (Purified Protein Derivative) was established. By 1940, there was an estimate of 13 to 14,000 tuberculosis-related deaths ${ }^{30}$.

Leprosy and pinta were also the subject of attention. A national campaign against leprosy led to the construction of the Pascua Hospital, created at the behest of Fernando Latapí, and that was opened on January 2 , 1937. The study of the second entity led to the identification of the causative agent by Salvador González Herrejón, and to the pathogen being named Treponema herrejoni in his honor, whereas, in 1939, Eduardo Aguirre Pequeño, in Monterrey, self-inoculated serum and contracted the disease, thus confirming its contagious nature and, most importantly, the transmission of the causative agent. 


\section{Malaria}

Malaria remained a serious health problem, and the campaign against it was thus declared of special interest in 1936. Special attention was put on characterizing endemic zones, with the coast in the adjacency between Tamaulipas and Veracruz being identified, and as a result of the fight against malaria having been officially declared of public utility in 1938, in 1939, on March 24, a postal stamp was issued, establishing that all resources generated by it would be applied to the eradication campaign. Nevertheless, this initial campaign, which was a continuation of those previously carried out by Liceaga early in the century, continued until 1956, when new guidelines were established.

The foundation of the Institute of Tropical Diseases focused all efforts on the study of this type of problems and constituted a milestone in the evolution of Mexican medicine. Its first director was Manuel Martínez Báez ${ }^{31}$.

\section{Onchocerciasis}

Onchocerciasis was not taken into consideration until the works by Lacombe in the decade of 1920. By 1935 , there were from 22,000 to 25,000 subjects affected in Chiapas and between 5000 and 8000 in Oaxaca. On April 13,1935, regulations were published establishing the campaign against it and, in 1940, extraordinary actions on the subject were carried out in both states.

\section{Cysticercosis}

Although taeniasis was well known, the presence of cysticerci in the brain was only detected in 1938, when Leopoldo Salazar Viniegra diagnosed and reported the first case of cerebral cysticercosis and José Rojo de la Vega operated a case of racemose cerebral cysticercosis at Hospital Juarez. One year later, Clemente Robles statistically showed the importance of cysticercosis at the General Hospital.

Other parasitoses came to light, such as Chagas disease in humans, which was detected in 1939 by Mazzotti in Oaxaca, with one case being reported in Yucatán one year later.

\section{Maternal and child care}

Concerns about women's health during pregnancy, delivery and the puerperal period, and of that of newborns, which had an important development during the previous decade, remained a priority.

One problem that had to be urgently addressed was malnourishment. Some actions had already been carried out, such as the "drop of milk", aimed to improve and ensure infant access to milk supply, while adequate weaning schemes were designed. The works of Manuel Cárdenas de la Vega, and then by Federico Gómez and Rigoberto Aguilar Pico, at the Casa de Cuna and Hospital Dolores Sáenz de Lavie, were fundamental, and already in 1934, Gabriel Araujo, on his college graduation thesis, proposed using chickpea flour in the diet. A series of clinical trials that took place later prompted Federico Gómez to precisely define malnourishment grades in the scale that continues to be used up to now ${ }^{32}$.

Pellagra was a disease that, always present, had been poorly studied. In Yucatán, between 1932 and 1936, Alvaro Carrillo Gil studied and published about xerophthalmia and pellagra (culebrilla), thus being a pioneer in malnourishment clinical study.

One of the main reasons for the development in health was maternal and child care, which aimed to decrease morbidity and mortality during pregnancy and delivery in the case of the mother, and during the first months of life in the case of the child. In 1936, the first units of this type of care were opened in Xalapa, Tuxpan and Coatzacoalcos, Veracruz, with the purpose to provide families with comprehensive, community-based care with programs of environmental sanitation, vaccination and medical care. In 1937, a new Autonomous Department of Social and Children's Assistance Department with breakfasts for children started operating in charge of Isidro Espinosa de los Reyes and Salvador Zubirán, and on that same year, Matilde Rodríguez Cabo published Birth Control pointing out eugenics and sexually transmitted diseases control most important issues, with congenital syphilis and purulent ophthalmia being two causes of great ailments. For the management of the latter, the use of silver-based drops (the Credé method) became mandatory. All this culminated in 1939 with the establishment of the National Campaign pro-mother and child. Previously, in 1937, the decision was made to give priority to the construction of hospitals for children, which would culminate with the foundation of the Children's Hospital. By 1940, maternal deaths had decreased to 56.5 per 10,000 .

\section{Sexually transmitted diseases}

Eliseo Ramírez promoted an anti-venereal campaign with the tendency to abolish regulated prostitution, 
which drove in 1936 to the creation of the Technical Section of the Campaign against venereal diseases. The educational aspect was covered by Alfonso Pruneda in his book The doctor and sexual education and, in 1939, the National League Against Venereal Hazard was established, with new dispensaries being founded for that precise purpose, all of which culminated in 1940 with the Campaign against venereal diseases, including syphilis, chancroid, blennorrhagia, venereal granuloma and Nicholas-Favre disease (Fig. 4).

\section{Addictions}

Addictions are another subject that acquired relevance during this period. Alcoholism played the most relevant role, but identification of other addictions and looking for medical solutions thereof was not neglected, especially marihuana and opiates dependence. On November 11, 1935, the Ministry of Public Assistance established an anti-alcoholic cooperation female sub-committee, and it was around this time when the Addicts Section was founded in La Castañeda asylum, under the ruling, promulgated by Leopoldo Salazar Viniegra in

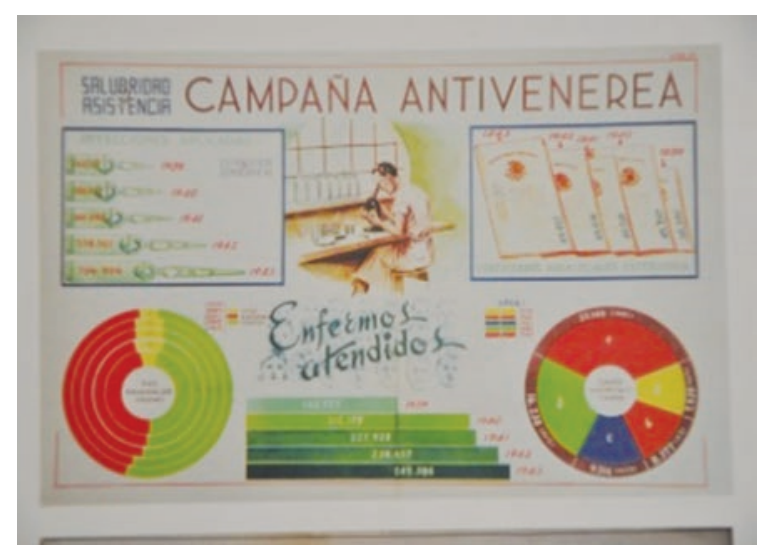

Figure 4. Campaign against sexually transmitted diseases. Department of Public Health.

1939, that drug-addicts are sick individuals, not criminals. It was in the same sense that, in order to prevent drug traffic, keeping a registry of addicts was established, where the type of drugs and doses they consumed were also recorded and, according to these data, with a strict control and by official prescription, they were to periodically be supplied the amount of drug specified by the Ministry of Assistance central pharmacy. 


\title{
Hospitals during the Cardenismo (1934-1940)
}

\author{
Guillermo Fajardo Ortiz \\ Subdivision of Continued Education, Division of Postgraduate Studies, Faculty of Medicine, Universidad Nacional Autónoma de México, \\ Mexico City, Mexico
}

\section{Political frameworks}

This historical sketch makes a brief review of important facts in hospitals of the six-year period (1934-1940); much water has flowed under the bridge ever since. At the beginning of that six-year term, gunshots were no longer heard, public authorities assumed there were serious and important problems of diverse nature, and they had social peace and legal life as purpose and obligation. The country reflected signs of change; these were post-revolutionary times. Writer Jean Meyer expressed: "after 24 years of almost uninterrupted violence, the last chapter of the revolutionary stage takes place between 1934-1940, with the pacific revolution conducted by president Lázaro Cárdenas, the first one to last six years in power"33. In the period under study, Mexico City was a remote place for the "hinterland". In States and territories, very few roads were paved, there were godforsaken roads, trains were slow, telephone lines were uncertain, time seemed to have frozen. On those years, new medical-sanitary paths were created, which were the consequence of the agrarian reform, the railroad nationalization, political asylum to Spanish exiles, the oil expropriation and technical-scientific advances. Hospitals originating in the colonial era or created in the Porfirista stage and structured during the armed times of the Mexican Revolution prevailed. In 1934 to 1940 hospitals there is philosophy, history, medicine, education and innovation, not only of that six-year period, but of the future. There is a large variety of medical-sanitary, social, political, economic and ethical information.

The paucity of reliable data with regard to the number of hospitals and beds therein at the national, state, territorial and local levels should be taken into account, but probably there were less than 200,000 hospital beds. At the conclusion of the six-year period under study, Mexico had 20 million inhabitants; therefore, maybe there was less than one bed per 1000 inhabitants, and there was no hospital certification.

Socioeconomic structural conditions, such as population dispersion across the national territory, combined with the scarcity of economic resources, led to hospital concentration in the cities (Fig. 5).

\section{Hospitals feet and heads}

From a technical and administrative point of view, hospitals were uncomplicated, and the equipment and instruments were simple. Medications were often magistral formulas. Medical care was in hands of the male gender, and practically there were no registered nurses.

Operating hospitals originated in the colonial epoch, the Porfirista times and the armed years of the Mexican Revolution. The former included the Hospital de Jesús in Mexico City and Hospital Belén in Guadalajara. Subsequently, today's Hospital General Dr. Eduardo Liceaga, in Mexico City, and the Hospital General O'Horan in Mérida, Yucatán, were created. Of the revolutionary times, there were Red Cross, Green Cross and White Cross nosocomial facilities; in this case these were "blood" establishments.

With regard to the branch of medicine, there were general and specialized hospitals. The latter included insane asylums, ophthalmologic establishments, maternity units, emergency hospitals, leprosaria, hospitals for tuberculosis patients and hospitals for the care of people with infectious-contagious diseases. General hospitals basically looked after so-called "acute" diseases, deliveries and accidents. Medical care levels were not known, and the International Classification of Diseases was practically unknown.

With regard to medical-architectonic design, hospital buildings basically corresponded to the clerical

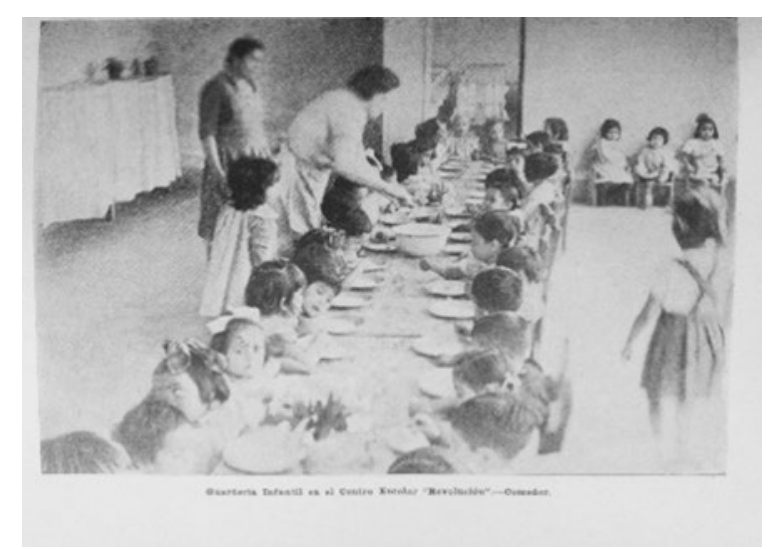

Figure 5. Child care center. (In: J. Álvarez Amézquita. Historia de la salubridad y de la asistencia en México, 1960.) 
type, which dated back to the colonial epoch, and to the pavilion-type, from the Porfirismo times. Vertical hospitals were built.

With regard to administrative dependence, there were four varieties: governmental, private initiative, military and private charitable organizations. Government-dependent hospitals included federal, state and municipal hospitals; in general, they were intended to serve the population in situation of poverty. In the area of private initiative, there were lucrative hospitals and those owned by workers. One example of the former was the Clínica Neuro-psiquiátrica Dr. Manuel Falcón, in Mexico City; the latter include those that were for miners, sugar mill workers, sugarcane collectors, film industry workers, oil industry workers, railroad workers and for some groups of bureaucrats, including the Ministry of Finance and Public Credit Hospital. Military hospitals were for members of the Ministry of War and Navy. Private charity hospitals belonged to the Spanish, French, American and British communities and were basically for their affiliates. This group included the Red Cross hospitals as well. In those years, as now, healthcare was fragmented and segmented, and there was inequity.

\section{Care to peasants}

In the governmental aspect, the federal authorities established in 1936 a health program for the rural sector dedicated to agrarian groups, known as "rural cooperative medical services". They were supported with symbolic fees paid by the peasant population and contributions of the federal government. With this model, locals were granted dignity. The services were an important expression, not only as regards addressing health problems, but they were also aimed to help and improve agricultural economy. The creation of these services was an extraordinary event. Indigenous people reappeared as important protagonists in medical care; men wearing coarse cotton clothing, huaraches and palm leaf hats. In addition to hospitals, services had rural hygiene centers and healthcare units as well. The latter addressed not only clinical problems, but also public health needs. There were facilities addressing potable water, drainage systems and septic tanks. Services' buildings were low-cost, they were settled on soil, sand and mud, they often lacked sufficient furniture and equipment, there was scarcity of medications and, even alcohol, which was considered to be indispensable, was lacking. In contrast, there was an enormous wish to help and serve the peasants on a 24-hour basis. This effort was the result of studies and work of sociologists, healthcare professionals and public servants, all of them passionate, optimistic and dreamer people. Documents of the Ministry of Public Health and Assistance historical archive state: "federal authorities broadened clinical and sanitary coverage, and created the collective medical-healthcare services, which depended on the rural hygiene central office". In another section, the written documents express: "in 1936, there were 36 units in all Mexico"34. Two important hospitals from these services were the Ciudad Anáhuac Hospital, in the State of Nuevo León, and the Mérida Hospital, in the State of Yucatán, which were reference units. The services followed somehow instructions issued by the Public Health section of the six-year plan formulated by Cárdenas government, inaugurated in $1934^{35}$.

\section{Hospital icons}

In the six years under study, the federal government built cutting-edge public hospitals, out of which three are mentioned: the Tuberculosis Hospital and the Institute of Public Health and Tropical Diseases in Mexico City, and the Zoquiapan Leprosarium, in the State of Mexico (Fig. 6).

As for the Hospital for Tuberculosis Patients, which was located in the zone known as Huipulco, it started operating in 1935 and depended on the Ministry of Assistance. Simultaneously, dispensaries were put together in the cities of Mérida, Hermosillo, Tampico, Veracruz, Jalapa and Mazatlán. The creation of dispensaries was a recognition of the medical-social importance given to tuberculosis. There were communicating vessels between preventive and curative issues.

In 1939, the Institute of Public Health and Tropical Diseases was opened. Its pillars were doctors Miguel Bustamante, Manuel Martínez Báez, Gerardo Varela and Eliseo Ramírez. The Institute constitutes a milestone in the history of clinical practice and public health: "it was the first institution for the research and study of diseases of interest for the country's public health" ${ }^{\prime \prime 6}$.

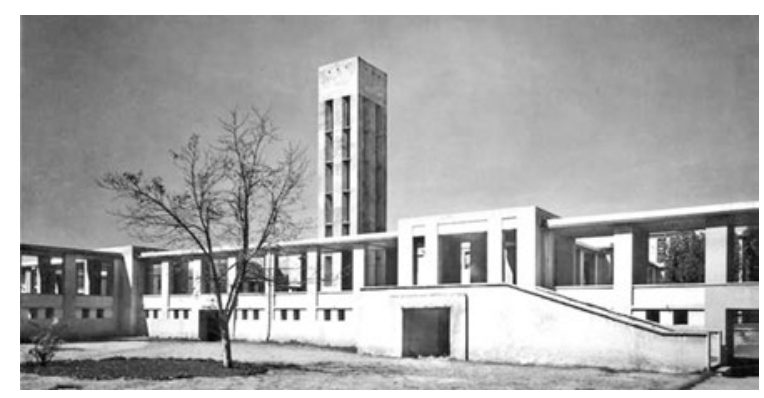

Figura 6. Hospital for tuberculosis patients of Huipulco. 
Initially, the Institute dealt with clinical, sanitary, teaching and investigative aspects referred to malaria, yellow fever, onchocerciasis, pinta and digestive parasitism.

In 1939, the high prevalence of leprosy prompted the foundation of the Pedro López Leprosarium in Zoquiapan, State of Mexico ${ }^{37}$, which was coordinated with anti-leprosy dispensaries. It should be mentioned that, in those days, lepers were seen with horror, as deformed, collapsing human beings, and they were marginalized. This caused for the establishment to become an authentic village over time. This leprosarium had within-walls housing, and there were carpentry, sewing and smithy workshops, a hair salon, a kitchen and even a cemetery.

\section{Medical services for railway workers}

As for hospitals for workers, they were financed by employers or workers, or both. With regard to the facilities for railroad workers, a network of medical services, now memorable and legendary, was created, which was comprised by the Colonia Hospital in the former Distrito Federal, "foreign" hospitals, first-aid posts, outpatient clinics and medical wagons. The Colonia Hospital left an overwhelming medical print in Mexico. It was a model, unique facility, built with iron, concrete and stone; it had modern furniture and equipment; it looked after general medicine and medical-surgery specialty problems, and it was one of the first vertical hospitals in Mexico. It started operating on September 19, 1936, in substitution for a hospital that was built based on wood. Not only railway workers were provided services in these facilities, but also private patients could be admitted.

\section{The beginninng of medical care in Petroleos Mexicanos}

Another facet that should be considered in the Cardenista period regarding hospitals for workers is related to the oil expropriation, an event occurred in 1938. Prior to that year, hospital care for oil-industry workers was insufficient and fragmented. There were few facilities, and some belonged to foreign oil companies. Most times, workers were provided hospital services at private or public institutions that were rented or subrogated; shortly after, that which was to become a great plan of medical-hospital services for the Petróleos Mexicanos personnel was initiated.

\section{Lucrative hospitals}

During this period of time, private hospitals, such as the Toriz Maternity in the city of Puebla, continued operating. Other facilities were founded all over the country, such as the San Luis Clinic in the city of San Luis Potosí, which opened its doors in 1934, and Dr. Manuel Falcón Neuropsychiatric Clinic in the Distrito Federal, which was opened in 1937.

\section{The "refugees" had hospitals}

During the years under study, political asylum was granted to Spanish emigrants. They were the socalled "refugees", who had problems to receive medical care in the facilities for Spaniards who were already residing in the country. The "refugees" created their own small hospitals. These were founded in Mexico City and other cities of the country. Patients were looked after by doctors who were also "refugees". One of the most widely known facilities in the Distrito Federal was Benéfica Hispana, an effort to even and make medical care accessible to all Spaniards.

To conclude, in the Cardenista six-year term, there was a renewal in hospital, construction and financial care. Furthermore, the ideological social and public bases were set for the creation of the Mexican Institute of Social Security medical services. 


\title{
Military medicine in Mexico during the Cardenismo (1934-1940)
}

\author{
Antonio Moreno Guzmán \\ Escuela Médico-Militar, Mexico City, Mexico
}

\section{Introduction}

General Lázaro Cárdenas del Río (Fig. 7) presidential term was the first one in Mexico that lasted 6 years, as a consequence of his electoral platform being based on the "six-year plan", and it was characterized, among other things, by a rupture with previous political structures of power and the beginning of a new economic, political, social and educational stage in post-revolutionary Mexico. As part of that new country vision and project, Cárdenas was a prominent promoter of the Military Healthcare Service modernization in Mexico.

\section{Background}

For a better understanding of general Cárdenas determined support to the Military Healthcare Service, it is necessary to remember that Lázaro Cárdenas joined the revolutionary troops since 1913 with the rank of second captain, and by 1928, he had already managed to reach the highest military hierarchy, the divisional general rank ${ }^{38}$.

It is also important highlighting that, during the de la Huerta rebellion on December 26, 1923, in the campaigns of the west of the country, in a battle that

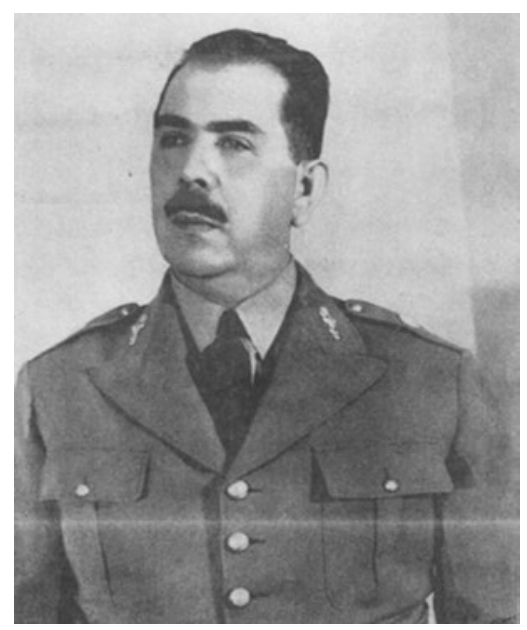

Figure 7. Divisional general Lázaro Cárdenas del Río, president of the Republic (1934-1940). (In: Archivo fotográfico de la Comisión de Estudios Históricos de la Escuela Médico-Militar). took place in Huejotitlán, Jalisco, general Cárdenas was defeated by general Rafael Buelna's troops, commanded by general Enrique Estrada. That day, Cárdenas was badly injured; he had a gunshot wound that penetrated the chest, with abundant hemothorax ${ }^{39}$, and was efficiently attended to by the military doctor of the $37^{\text {th }}$ Infantry Battalion of Aguascalientes, major medical surgeon (MS) Adolfo Ochoa y Mena, graduated from the Medical-Military School in 1923, who, by the way, also was wounded, but less severely, and owing to the injuries sustained by both and to the impossibility to evacuate general Cárdenas, he decided to stay at his wounded patient's side, even when general Cárdenas himself had ordered him to leave. Both had been taken prisoner by Delahuertista rebel general Estrada, who by the way treated them both very diligently, to the point that he provided them with the means and ordered major MS Ochoa to evacuate general Cárdenas to Guadalajara, and he brought him to Dr. Carlos Barrier hospital, from that moment on remaining under the care of Dr. Alberto Onofre. Once both were recovered from their injuries, he released them offering them the choice of joining the rebellion or returning to the government troops where they belonged and, both general Cárdenas and major MS Ochoa decided to rejoin the federal forces ${ }^{40}$.

Finally, when he was already president of the Republic, the pediatrician of his son Cuauhtémoc was the then lieutenant colonel MS Federico Gómez Santos $^{41}$, who was an authority in national pediatrics and few years later one of the founders of the Children's Hospital of Mexico. Undoubtedly, the described events surely made general Cárdenas particularly sensitive to listen to the Military Medical Corps needs in order to improve healthcare conditions of Mexican soldiers.

\section{Military medicine during general Cárdenas six-year term}

At general Cardenas inauguration as president of the Republic on December 1, 1934, the Military Healthcare Service had one Military General Hospital, 
one medicine Warehouse, one Ambulance Train Regiment, one Isolation Hospital, 15 foreign Military Hospitals, 6 Military Infirmaries, 116 Sanitary Sections and two First-aid posts ${ }^{42}$, and although in "plain numbers" this would appear to be sufficient, the reality was quite different, since the Army's medical services, as practically all such services in the country, were at very precarious operational conditions. For that reason, military healthcare modernization initiatives launched by general Cárdenas were highly significant for the health of military personnel and their families.

At the beginning of the Cardenista six-year term, Brigadier General MS José Siurob Ramírez was the head of the Military Health Department, a post that he held from December 16, 1934 to June 15, 1935, when he was appointed director of the Health Department (today's Ministry of Health). He was substituted by Brigadier General MS Andrés G. Castro, who, in turn, on November 1, 1935, was relieved by Brigadier General MS Ignacio Sánchez Neira - general Cárdenas fellow party member-, who remained on that post for little over 11 years, until January 31, 1947. Undoubtedly, Doctor Sánchez Neira's prolonged permanence in charge of the Military Health Department and his influence were key pieces in the projects to build both the Central Military Hospital and the Military Medical School ${ }^{43}$ (Fig. 8).

In the year of 1936, by initiative of Major MS Gustavo Gómez Azcárate, the order was issued for all Army members to have their blood type determined since, according to different national studies and others conducted by him, it was concluded that blood transfusions were a highly important therapeutic

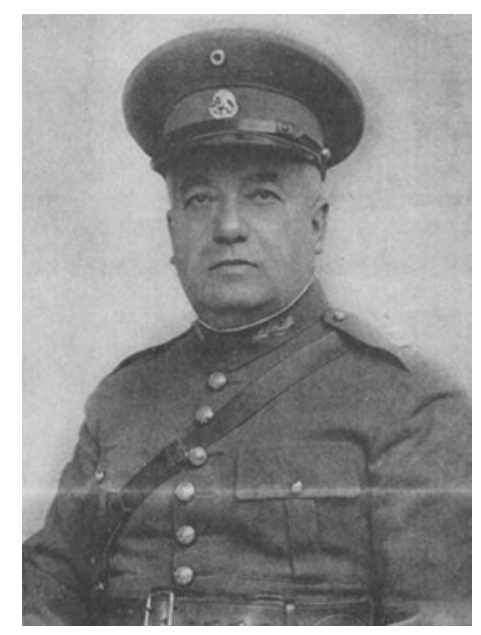

Figure 8. Brigade General MS Ignacio Sánchez Neira, director of Military Health (1935-1947). (In: Archivo fotográfico de la Comisión de Estudios Históricos de la Escuela Médico-Militar). resource in the treatment of severely wounded patients, a measure by means of which an improvement in the diagnosis and treatment of patients with hemorrhagic shock was gradually initiated ${ }^{44}$.

Also in 1936, a so far unprecedented and surely unrepeatable fact took place: on May 2 of that year, Colonel MS Gustavo Baz Prada, former student of the Military Practical School and the National School of Medicine $^{45}$, was appointed director of the Military Medical School and, simultaneously, he was also appointed director of the National School of Medicine, which he would direct from October 1935 until June 21,1938 , when he was appointed rector of the National Autonomous University of Mexico ${ }^{46}$, with his duty as director of the Military Medical School concluding on August 1938, once more evincing the absolute trust general Cárdenas and the University Board itself placed on military doctors.

It is also pertinent mentioning that, during the fateful years around the oil industry expropriation, Mexico's plenipotentiary ambassador before the USA was Brigadier General MS Francisco Castillo Nájera, who fulfilled that duty from 1935 to 1945 and was in charge of wading through the diplomatic gale that was unleashed as a consequence of the expropriation and World War II. It is also important mentioning that Dr. Castillo Nájera had been chairman of the National Academy of Medicine in $1927^{47}$.

In addition, on that same year, at the Military General Hospital, the department of orthopedics was created by Major MS Ignacio Sánchez Díaz (which had already been proposed since 1932), the plastic surgery pavilion was created by Major MS Joaquín de Castillo Angulo, who also proposed its teaching to be included in Military Medical School classes and, finally, the ward for venereal diseases, which in those years continued to be a plague among the military population, was also created ${ }^{48}$. Finally, on September 10, 1936, the First National Convention of Military Physicians was celebrated, with the venue being none other than the Palace of Fine Arts, which had been recently opened, in 1934. The event was attended by General Lázaro Cárdenas, President of the Republic, and by Generals Andrés Figueroa and Manuel Ávila Camacho, secretary and sub-secretary of War and Navy, respectively. With no doubt, this also denotes the high esteem the Military Medical Corps were held in during those years ${ }^{49}$.

It was precisely during this Convention that general Cárdenas made the official announcement of the construction of the future Central Military Hospital, the 
first stone of which he had laid on August 13, 1936, and for which purpose he created the Central Military Hospital Organizing and Building Commission ${ }^{50}$ and pieces of land were acquired from Lomas de Sotelo, at the western area of the city, where the buildings of the Central Military Hospital, the Military Medical School and the Ministry of National Defense, formerly known as Ministry of War and Navy and designed like this since September 1, 1937, were erected.

Early in Cárdenas' six-year term, since June 1935, lieutenant colonel MS Manuel Pérez Amador and Major MS Guillermo Román Carrillo were sent to Berlin, Germany, to arrange the acquisition of equipment for the future Central Military Hospital and, by 1937, the devices, machinery, furniture, equipment and instruments started arriving from Germany to the Central Military Hospital, which was still under construction and was opened only until November 20, 1942. Curiously enough, the works were initiated when General Cárdenas was president of the Republic and General Ávila Camacho was the secretary of War and Navy ${ }^{51}$, and when they concluded, the president of the Republic was General Ávila Camacho and the secretary of the Ministry of National Defense was General Cárdenas, which is also surely a historical unrepeatable fact ${ }^{52}$.

Undoubtedly, the year of 1938 will remain indelible in Mexican historical memory as the year if the oil industry expropriation orchestrated by president Cárdenas, but in particular for the Military Health Service. With all due reserves, the most impacting events were when the flag was presented for the first time to the Military Medical School on September 15, 1938 at the National Stadium, handed over by the secretary of the Ministry of National Defense, general Ávila Camacho, and most particularly, the birth of the School for Army Nurses, the creation of which was decreed by Lázaro Cárdenas on March 21, 1938, although it should be clarified that, since 1894, colonel MS Fernando López y Sánchez Román, at that time director of the Instruction Military Hospital, initiated the course for military nurses training within the military hospital, and when he was assigned as General Hospital of Mexico first director, in 1905, he immediately opened the course for civilian nurses in that hospital. Although since the last few years of the $19^{\text {th }}$ century there were female nurses in the army, it was until president Cárdenas decreed the creation of the School for Army Nurses that academic specialized and specific training of Mexican military nurses was initiated.
This School was located within the General Military Hospital in 1938, with its first director being colonel MS Donato Moreno Muro53, and by 1942, it occupied the north and south wings of first section sixth floor of the then recently opened Central Military Hospital. Years later, in 1946, the School changed its name for Military School for Nurses and Midwives, to finally arrive to its current denomination of Military School for Nurses, as of 1963. At the beginning, all students were external and gradually they went on assimilating until, in 1952, all cadets were included in the permanent internship system throughout their studies.

As for their military hierarchy, although since 1947 they graduated with the sub-lieutenant nurse rank, this was officially established until president Ruiz Cortines January 15, 1957 decree, which also specified that they were able to ascend in the hierarchical scale, by means of a rigorous promotion exam, up to the first captain nurse rank; this situation has been changing over the years, and currently they reach the colonel nurse rank while on active service.

Finally, this School was moved to the Central Military Hospital in 1964 and, since 2011, its students graduate with the sub-lieutenant nurse military rank and the academic degree of registered nurse ${ }^{54}$.

As for males dedicated to military nursing, the following should be mentioned: as background of the Military School for Health Officers, it is essential mentioning that, since February 21, 1927, major MS Juan Gil Saldaña started, although irregularly, a school for the training of male nurses for the service of the army. It was born owing to major MS Saldaña concern to create a school to train Military Male Nurses and Stretcher-bearers that were able to assist the military physician with his technical, tactical and administrative activities, and especially to provide first aid to those wounded in combat. For this reason, courses started irregularly at the Instruction Military Hospital, and it was until 1937 that major MS Saldaña Alcocer saw his project crystallized, when the first formal course with curriculum was authorized, although with no budget for this purpose. The first 37 students entered with an admission profile that included, among other aspects, having incomplete nursing or medical education, and vocation for a career in the healthcare and wounded care area ${ }^{55}$. It was until October 23, 1939 when, by presidential decree of Lázaro Cárdenas, the School of Male Military Nurses was officially created, which was established within the General Military Hospital, with no budget and with external students. Some years later, by President Manuel Ávila 
Camacho's April 15, 1943 decree, the School was moved in January 1, 1944 to the Central Military Hospital and officially opened on January 17,1944 , with the flag presented by the secretary of the Ministry of National Defense until April 30, 1947 at the Central Military Hospital promenade ${ }^{56}$.

On July 19, 1954, the name of School of Male Military Nurses was changed to School of Military Health Officers, according to the presidential decree of July 5, 1954. On November 9, 1970, it was provided a building of its own, and its name was finally changed for the current one of Military School of Health Officers. Since 2011, its students are graduated with the military rank of sub-lieutenant of health and a college degree in public health and medical emergencies ${ }^{57}$.

\section{Considerations}

The unprecedented support received by the Military Health Service from president Lázaro Cárdenas was decisive for Mexican military medicine to reach its full development in the second half of the $20^{\text {th }}$ century, by changing Mexico City's western urban landscape forever with the construction of the new Central Military Hospital, initiated by general Lázaro Cárdenas in 1936 and concluded by general Manuel Ávila Camacho in 1942, and that at the moment of its opening was the first vertical hospital of the nation and the largest and most modern of all Latin America, with an installed capacity of 1000 beds and with a system of care for army members and their families that was taken as a model and soon was to be replicated in the social security nascent institutions of our country ${ }^{58}$.

Furthermore, general Cárdenas completed the project of the Central Military Hospital construction with the creation of the nursing schools for females and males, the Military School for Army Nurses in 1938 and the School of Military Male Nurses in 1939, by means of which he undoubtedly strengthened the quality of care received by army members and their families ever since. 


\title{
Final conclusions of the Symposium
}

\author{
Martha Eugenia Rodríguez \\ Department of History and Philosophy of Medicine, Faculty of Medicine, Universidad Nacional Autónoma de México, Mexico City, Mexico
}

The Mexico that was governed by General Lázaro Cárdenas del Río was complex. It was characterized by shortages, insalubrity, malnourishment (especially in children) and diseases of poverty, such as infectious-contagious conditions, including typhus and leprosy, which could be largely prevented by means of education. To combat the medical-sanitary situation, the six-year government undertook important policies that modified morbidity and mortality statistics of the country. In 1934, life expectancy at birth was 33 years, and by 1940 it was 41.5 years. Death rate went from 26.6 to 22.8 per 1000 population. The results were due to government interest, which increased health budget. Furthermore, they were due to institutional work, to measures taken by the Department of Public Health, but also to the work of other organizations, including the Coordinated Services that would reach rural zones, the Institute of Hygiene, the School of Public Health, the Institute of Public Health and Tropical Diseases, the Ministry of Public Assistance and different general and specialized civil and military hospitals.

The campaigns against diseases played an important role, fundamentally for those caused by microbes, viruses, parasites and vectors. These were well-implemented campaigns that contemplated patient care, health education, hygienic habits, sanitary engineering, etc. Not only doctors participated in the campaigns, but also visiting nurses, engineers and technicians.

In turn, the hospital network was broad. Cutting-edge public hospitals were set up, including the Tuberculosis Hospital and the Leprosarium in Zoquiapan, State of Mexico. Coverage was also provided to railway workers, to oil-industry workers and to Spanish refugees and, during the Cardenismo, the construction of the new Central Military Hospital was initiated. The Military Health Service was the subject of an unprecedented boost; in addition to starting with the building of the above-mentioned hospital, nursing schools for males and females were created. In short, it can be claimed that, during the Cardenismo, the balance in matters of health was positive. It initiated a control for infectious-contagious diseases that laid the bases for future works, to such an extent that, today, chronic conditions are more concerning.

\section{References}

1. González Marín S, Bosque Lastra M. Logros del cardenismo. México: UNAM, Instituto de Investigaciones Bibliográficas, Biblioteca y Hemeroteca Nacionales; 1996. p. 27.

2. Aguilar Rivera JA. Los gobiernos posrevolucionarios, 1921-1945. En: Florescano E, coordinador. Arma la historia. La nación mexicana a través de dos siglos. México: Grijalbo; 2009. p. 187.

3. INEGI. Población. Disponible en: http://www.beta.inegi.org.mx/temas/ estructura

4. Aguilar Rivera JA. Los gobiernos posrevolucionarios, 1921-1945. En: Florescano E, coordinador. Arma la historia. La nación mexicana a través de dos siglos. México: Grijalbo; 2009. p. 188.

5. González Marín S, Bosque Lastra M. Logros del cardenismo. México: UNAM, Instituto de Investigaciones Bibliográficas, Biblioteca y Hemeroteca Nacionales; 1996. p. 42.

6. Cárdenas C. Cárdenas por Cárdenas. México: Penguin Random House Grupo Editorial; 2016. p. 404.

7. Campos Navarro R. La antropología médica hace su primera aparición en México en la Escuela Superior de Medicina Rural del IPN. En: Medicina mexicana, dos siglos de historia, 1810-2010. Viesca C, coordinador. México: Bayer de México; 2011. p. 317.

8. Baz G. Palabras de Gustavo Baz en septiembre de 1936 al enviar a los primeros 260 estudiantes al campo mexicano en servicio social. En: Conmemoración del cincuenta aniversario de la instauración del servicio social en México. México: Secretaría de Salud, 1986, p.19. Agostoni C, Ríos Molina A. Las estadísticas de salud en México. Ideas, actores e instituciones, 1810-2010. México: UNAM y Secretaría de Salud; 2010. p. $179-80$

9. Álvarez Amézquita J,et al. Historia de la salubridad y de la asistencia en México. México: Secretaría de Salubridad y Asistencia; 1960, II: 382.

10. Aguilar Rivera JA. Los gobiernos posrevolucionarios, 1921-1945. En: Florescano E, coordinador. Arma la historia. La nación mexicana a través de dos siglos. México: Grijalbo; 2009. p. 190.

11. Souza MI. Isaac Costero: vivir para la ciencia. México: Academia Nacional de Medicina, CONACYT, Intersistemas S.A. de C.V.; 2014. p. XVII.

12. Carrillo AM. Salud pública y poder en México durante el Cardenismo, 1934-1940. En: DYNAMIS. Acta Hisp Med Sci Hist Illus. 2005;25:145-78.

13. Archivo Histórico de la Secretaría de Salud (AHSSA). Fondo: Salubridad Pública. Sección: Presidencia. Serie: Acuerdos presidenciales. C. 47, exp. 29 , f. 57.

14. AHSSA, F: CSG, Actas, c. 1, exp. 1, p. 202

15. Prida M. La enfermera en la campaña contra las enfermedades transmisibles. En: Memoria de la Cuarta Asamblea Nacional de Cirujanos. México; 1940. p. 275-8

16. AHSSA, F: Salubridad Pública, S: Presidencia, Se: Acuerdos presidenciales, L. 1, exp. 1, f. 41.

17. Álvarez Amézquita J,et al.Historia de la salubridad y de la asistencia en México. México: Secretaría de Salubridad y Asistencia; 1960, II: 439.

18. Aboites Aguilar L. El último tramo, 1929-2000. En: Nueva historia mínima de México. 5. ${ }^{a}$ reimp. México: El Colegio de México; 2008. p. 262-302.

19. Cárdenas L. Discurso al protestar como presidente de la República ante el Congreso de la Unión el 30 de noviembre de 1934. En: Los presidentes de México ante la nación. 1821-1966. 4 vols. México: CXLVI Legislatura, Cámara de Diputados; 1966. IV: 11

20. Cárdenas L. Informe de Gobierno, $1^{\circ}$ de septiembre de 1935, En: Los presidentes de México ante la nación. 1821-1966. 4 vols. México: CXLVI Legislatura, Cámara de Diputados; 1966. IV: 34-35.

21. Cárdenas L. Informe de gobierno, $1^{\circ}$ de septiembre de 1936. En: Los presidentes de México ante la nación. 1821-1966. 4 vols. México: CXLVI Legislatura, Cámara de Diputados; 1966. IV: 59-60.

22. Alba F. Crecimiento demográfico y transformación económica, 19301970. En: vv.aa. El poblamiento de México. IV. México en el siglo XX. México: Secretaría de Gobernación/CONAPO; 1993. p.77-80.

23. Benítez Zenteno R. La expansión demográfica de México, 1895-1970. En: Dinámica de la población de México. México: El Colegio de México; 1970. p. 5-11

24 Bustamante ME. Gac Med Mex. 1934;LXV:181-4. Reproducido en: Agostoni C, Ríos Molina A. Las estadísticas de salud en México. Ideas, actores e instituciones, 1810-2010. México: UNAM/Secretaría de Salud; 2010.p.207-20. 
25. Angelini A. La higiene y la medicina sociales. Gac Med Mex. 1933; LXIV:122-36.

26. Alonso Concheiro A. Cronología médica mexicana. Cinco siglos. México: Consejo de Salubridad General/Academia Nacional de Medicina/Academia Mexicana de Cirugía/Siglo Veintiuno editores; 2010. p.202.

27. Bustamante $M$, Viesca $C$, Villaseñor $F$, et al. La salud pública en México, 1959-1982. México: SSA; 1982.

28. Bustamante M. Observaciones sobre la mortalidad general en México, de 1922 a 1969. En: Almada Bay I, compilador. La mortalidad en México. 1922-1975. México: IMSS; 1982. p. 45-56.

29. Álvarez Amézquita J, Bustamante ME, López Picazos A, Fernández del Castillo F. Historia de la salubridad y de la asistencia en México. 4 vols. México: Secretaría de Salubridad y Asistencia; 1960. Vol. III.

30. Celis A, Nava J. Patología de la pobreza. En: Almada Bay I, compilador La mortalidad en México. 1922-1975. México: IMSS; 1982 p. 297-314.

31. Valdespino G, JL, Río Z, A del, Escobar G, A, Mora G, JL, editores. Una Institución Académica Mexicana y dieciséis investigadores distinguidos. Quincuagésimo aniversario del INDRE. México: INDRE, Secretaría de Salud; 1994.

32. Viesca C, Díaz de Kuri M. El Hospital Infantil de México. 50 años de Historia. México: Hospital Infantil; 1993

33. Meyer J. México entre 1934 y 1998. En: Historia de México. Van Wobeser G, coordinadora. México: Academia Mexicana de la Historia, Fondo de Cultura Económica; 2010. p. 249.

34. Archivo Histórico de la Secretaría de Salubridad y Asistencia. Fondo Salubridad Pública. Sección 5, Caja 5, Expediente 10.

35. Villalbazo Reyes JA, Morales Meneses J, elaboradores; Alonso Gutiérrez JF, coordinador. Guía del Fondo Beneficencia Pública. Addenda. México: Secretaría de Salud, Oficialía Mayor: 1990. p. V, VI.

36. Martínez Barbosa X, Martínez Cortes F, Rivero Serrano O. El Consejo de Salubridad General (1925-2000). México: Smith Kline Beecham 2000. p. 45.

37. Chávez I. México en la cultura médica. México: Biblioteca de la Salud Instituto de Salud Pública, Fondo de Cultura Económica; 1987. p. 143.

38. Poblett-Miranda M. Lázaro Cárdenas. En: Villapando JM, director Grandes protagonistas de la historia mexicana. México: Planeta De Agostini; 2002.p.153.

39. Krauze E. Lázaro Cárdenas, general misionero. 1aㅡ edición, 5 $5^{\underline{a}}$ reim presión. México: Fondo de Cultura Económica;2002. p. 24

40. Lozoya Solís J. La Escuela Médico Militar de México. México: Edición del autor;1977. p.81.

41. Lozoya Solís J. La Escuela Médico Militar de México. México: Edición del autor;1977. p.271.
42. Gutiérrez SJL. Historia del Servicio de Sanidad Militar en México. Tomo III. Ciudad de México: Estado Mayor de la Secretaría de la Defensa Nacional; 1987. p. 186.

43. Gutiérrez SJL. Historia del Servicio de Sanidad Militar en México. Tomo III. Ciudad de México: Estado Mayor de la Secretaría de la Defensa Nacional; 1987. p. 190.

44. Gutiérrez SJL. Historia del Servicio de Sanidad Militar en México. Tomo III. Ciudad de México: Estado Mayor de la Secretaría de la Defensa Nacional; 1987. p. 193.

45. García-Procel E, coordinador. Academia Nacional de Medicina de México. Presidentes 1864-2006. p.61.

46. Gustavo Baz Prada.(Consultado el 12 de agosto de 2016.)Disponible en: http://bibliohistorico.juridicas.unam.mx/libros/1/254/100.pdf

47. García-Procel E, coordinador. Academia Nacional de Medicina de México. Presidentes 1864-2006. p.53.

48. Gutiérrez SJL. Historia del Servicio de Sanidad Militar en México. Tomo III. Ciudad de México: Estado Mayor de la Secretaría de la Defensa Nacional; 1987. p. 197.

49. Gutiérrez SJL. Historia del Servicio de Sanidad Militar en México. Tomo III. Ciudad de México: Estado Mayor de la Secretaría de la Defensa Nacional; 1987. p. 195.

50. Moreno-Guzmán A. Historia de la cirugía general en el Hospital Central Militar. Rev Sanid Milit Mex 2013;67:128-35

51. Ruiz-Massieu A, Flores ME. Gabinetes presidenciales. México: Costa-Amic; 1988.p.192.

52. Moreno-Guzmán A. La formación de los cirujanos militares mexicanos, 1947-1970. México: Edición del autor; 2016. p.67.

53. Calva CE. Donato Moreno Muro. Coronel Médico Cirujano. Rev Sanid Milit Mex.2006:60:429-35.

54. Escuela Militar de Enfermeras. Cuna de mujeres leales. 75 aniversario. México: Secretaría de la Defensa Nacional, Dirección General de Comunicación Social; 2015.p. 62.

55. Moreno-Guzmán A. El Cuerpo Médico Militar y el Servicio Sanitario durante la Revolución Mexicana. Rev Sanid Milit Mex. 2014;68:325-40.

56. Gutiérrez SJL. Historia del Servicio de Sanidad Militar en México. Tomo III. Ciudad de México: Estado Mayor de la Secretaría de la Defensa Nacional; 1987. p. 208.

57. Centro Militar de Ciencias de la Salud. México: Secretaría de la Defensa Nacional, Dirección General de Comunicación Social, Sección de Difusión Interna; 2016. p. 45

58. Sánchez NI. El Hospital Central Militar. Gral.de Bgda. M. C. Ignacio Sánchez Neira. Director de Sanidad Militar. México: Edición del autor; 1943 